\title{
Echocardiographic assessment of arrhythmogenic right ventricular cardiomyopathy
}

\author{
L Lindström, U M Wilkenshoff, H Larsson, B Wranne
}

\begin{abstract}
Objective-To evaluate new echocardiographic modes in the diagnosis of arrhythmogenic right ventricular cardiomyopathy (ARVC).

Design-Prospective observational study.

Setting-University Hospital.

Subjects-15 patients with ARVC and a control group of 25 healthy subjects.

Methods-Transthoracic echocardiography included cross sectional measurements of the right ventricular outflow tract, right ventricular inflow tract, and right ventricular body. Wall motion was analysed subjectively. M mode and pulsed tissue Doppler techniques were used for quantitative measurement of tricuspid annular motion at the lateral, septal, posterior, and anterior positions. Doppler assessment of tricuspid flow and systemic venous flow was also performed.

Results-Assessed by $M$ mode, the total amplitude of the tricuspid annular motion was significantly decreased in the lateral, septal, and posterior positions in the patients compared with the controls. The tissue Doppler velocity pattern showed decreased early diastolic peak annular $\left(\mathrm{E}_{\mathrm{A}}\right)$ velocity and an accompanying decrease in early $\left(\mathrm{E}_{\mathrm{A}}\right)$ to late diastolic $\left(\mathrm{A}_{\mathrm{A}}\right)$ velocity ratio in all positions; the systolic annular velocity was significantly decreased only in the lateral position. Four patients had normal right ventricular dimensions and three were judged to have normal right ventricular wall motion. The patient group had also a significantly decreased tricuspid flow E:A ratio.

Conclusions-Tricuspid annular measurements are valuable, easy to obtain, and allow quantitative assessment of right ventricular function. ARVC patients showed an abnormal velocity pattern that may be an early but non-specific sign of the disease. Normal right ventricular dimensions do not exclude ARVC, and subjective detection of early changes in wall motion may be difficult.
\end{abstract}

(Heart 2001;86:31-38)

Keywords: annular motion; diastolic dysfunction; right ventricular function; tissue Doppler

Arrhythmogenic right ventricular cardiomyopathy (ARVC) is characterised by progressive fibrofatty replacement of the right ventricular myocardium $^{12}$ which constitutes a substrate for electrical instability and a focus of ventricular arrhythmias. Clinically, ARVC usually presents with ventricular arrhythmias, ${ }^{3}$ and there is growing evidence that this is the underlying disease in a substantial number of sudden deaths among young, apparently healthy individuals. ${ }^{4-6}$ The diagnosis of ARVC relies on the presence of structural and functional abnormalities of the right ventricle, electrophysiological abnormalities, and a family history. ${ }^{7}$ Echocardiography plays an important role in the evaluation of patients with suspected ARVC. However, it has many limitations in the assessment of right ventricular function, ${ }^{8}$ and there is still no generally recommended method for quantifying the function of the right ventricle. Measurement of tricuspid annular motion has been proposed as a method for estimating right ventricular systolic function, ${ }^{9}$ and it has been found to correlate well with the right ventricular ejection fraction. ${ }^{10}$

Our aim in this study was to describe the echocardiographic findings in patients with ARVC, paying special attention to the added value of measurement of tricuspid annular motion by $\mathrm{M}$ mode and pulsed tissue Doppler.

\section{Methods}

PATIENTS

We studied 15 patients (10 men, five women) aged 22-59 years (mean 39) affected by ARVC. The clinical diagnosis was based on the criteria proposed by McKenna and colleagues. ${ }^{7}$ Some clinical characteristics are given in table 1 .

Ten patients had a history of syncope or palpitations. Ventricular tachycardia of left bundle branch block morphology was confirmed in nine of these, and supraventricular tachycardia in one. The time from the first presentation of cardiac symptoms to carrying out the present study ranged from less than one year to 16 years. No patients had any clinical suspicion of ischaemic heart disease; however, four patients (cases 3, 13, 14, and 15) had undergone coronary angiography, which was normal in all cases.

Four patients from two different families were investigated because of a family history of sudden death where ARVC was confirmed at necropsy of the relative. These four patients were asymptomatic but had shown frequent ventricular premature beats on earlier resting ECG or during an exercise test.

One patient (case 7) had an abnormal ECG with ventricular premature beats on health screening. She was the only patient in whom the echocardiographic finding was necessary to fulfil the proposed criteria for ARVC. ${ }^{7}$ 
Fourteen patients underwent percutaneous endomyocardial biopsy from the right ventricle. A standard ECG was recorded in all patients. In all except one patient, we performed signal averaged ECGs based on time domain analysis and with the high bandpass filter fixed at $40 \mathrm{~Hz}$. Abnormal values were defined according to the recommendations of Breithardt and colleagues. ${ }^{11}$ None of the patients had systemic hypertension, pulmonary disease, or significant valvar heart disease. At the time of evaluation, eight patients were on sotalol, one on metoprolol, one on metoprolol and amiodarone, one on amiodarone and mexiletine, and one on amiodarone and sotalol. Two patients (cases 4 and 14) had an automatic cardioverter-defibrillator implanted.

NORMAL POPULATION

In order to establish local reference values of right ventricular dimensions and tricuspid annular motion, a group of 25 normal subjects (11 male, 14 female) aged 21-75 years (mean 38) were examined. The subjects were mostly medical students or acquaintances of the authors. All were subjectively healthy. None had a history of cardiovascular disease or medical treatment. They had normal blood pressure, a normal physical examination, and a normal standard ECG and echocardiogram.

ECHOCARDIOGRAPHIC STUDIES

All studies were performed using an Acuson $128 \mathrm{XP}$ instrument (Acuson Corporation, Mountain View, California, USA) equipped with software for Doppler tissue imaging. A 2.5 or $3.5 \mathrm{MHz}$ phased array transducer was used.
The subjects were in the left lateral recumbent position except when imaging from the right supraclavicular window, when they were turned to the supine position.

For evaluation of the right ventricle, images were obtained from multiple standard views. ${ }^{12}$ From the apical window, we recorded tricuspid annular motion at four different positionslateral, septal, posterior, and anterior-using cross sectional guided $\mathrm{M}$ mode. Both the total amplitude and the atrial component were calculated as described by Hammarström and colleagues. ${ }^{9}$ Tricuspid annular motion was also recorded by pulsed tissue Doppler from the same four locations. This was done by placing the sample volume ( $4 \mathrm{~mm}$ ) in the bright area of the tricuspid annulus, taking care to align the ultrasound beam as parallel as possible to the motion. Recordings from the lateral and septal positions were made from the standard four chamber view (fig 1A). However, in some patients it was necessary to move the transducer medially and caudally from the standard position to get optimal alignment in relation to the motion.

Recordings from the anterior and posterior positions were made by tilting the transducer anteriorly or posteriorly, respectively, until the motion of the tricuspid valve disappeared, and then centring the sample volume within the annulus. The peak annular velocities in systole $\left(\mathrm{S}_{\mathrm{A}}\right)$, early diastole $\left(\mathrm{E}_{\mathrm{A}}\right)$, and late diastole $\left(\mathrm{A}_{\mathrm{A}}\right)$ (fig 1$)$ and the peak early to late $\left(\mathrm{E}_{\mathrm{A}}: \mathrm{A}_{\mathrm{A}}\right)$ diastolic ratio were calculated. Using conventional pulsed Doppler, the tricuspid flow was recorded from the apical four chamber view. The peak early diastolic (E), late diastolic (A), and

Table 1 Clinical characteristics and echocardiographic findings in 15 patients with arrhythmogenic right ventricular cardiomyopathy

\begin{tabular}{|c|c|c|c|c|c|c|c|c|c|c|c|}
\hline \multirow[b]{2}{*}{ Case } & \multirow[b]{2}{*}{$\begin{array}{l}\text { Age (years)/ } \\
\text { sex }\end{array}$} & \multirow[b]{2}{*}{$\begin{array}{l}\text { Clinical } \\
\text { presentation }\end{array}$} & \multirow[b]{2}{*}{$\begin{array}{l}\text { Time from first } \\
\text { symptom }\end{array}$} & \multicolumn{2}{|l|}{$E C G$} & \multirow[b]{2}{*}{$S A E C G$} & \multirow[b]{2}{*}{$R V$ biopsy } & \multirow{2}{*}{$\begin{array}{l}R V \\
\text { dilatation } \\
A / T\end{array}$} & \multirow[b]{2}{*}{$\begin{array}{l}R V W M \\
\text { score } A / T\end{array}$} & \multirow[b]{2}{*}{$\begin{array}{l}T A M \leq 20 \\
\text { mm, } M \text { mode }\end{array}$} & \multirow[b]{2}{*}{$\begin{array}{l}\text { TAM E: } A \leqslant 1 \text {, } \\
\text { tissue Doppler }\end{array}$} \\
\hline & & & & $\begin{array}{l}\text { Negative } \\
\text { T waves }\end{array}$ & E wave & & & & & & \\
\hline 1 & $58 / \mathrm{F}$ & VT & 7 years & V1-V2 & - & - & $\begin{array}{l}\text { Fat, } \\
\text { fibrosis }\end{array}$ & $2 / 3$ & $5 / 11$ & - & + \\
\hline 2 & $53 / \mathrm{M}$ & VT & 16 years & V1-V5 & + & + & $\begin{array}{l}\text { Fat, } \\
\text { fibrosis }\end{array}$ & $2 / 3$ & $8 / 9$ & + & + \\
\hline 3 & $49 / \mathrm{M}$ & VT & 16 years & V1-V3 & - & + & $\begin{array}{l}\text { Fat, } \\
\text { fibrosis }\end{array}$ & $3 / 3$ & $10 / 10$ & + & + \\
\hline 4 & $47 / \mathrm{M}$ & VT & 11 years & V1-V3 & - & + & $\begin{array}{l}\text { Fat, } \\
\text { fibrosis }\end{array}$ & $3 / 3$ & $9 / 9$ & + & + \\
\hline 5 & $45 / \mathrm{F}$ & Syncope & 6 years & $\mathrm{V} 1-\mathrm{V} 4$ & - & - & $\begin{array}{l}\text { Fat, } \\
\text { fibrosis }\end{array}$ & $0 / 3$ & $0 / 8$ & - & + \\
\hline 6 & $39 / \mathrm{M}$ & SVT & 2 years & $\mathrm{V} 1-\mathrm{V} 2$ & - & + & $\begin{array}{l}\text { Fat, } \\
\text { fibrosis }\end{array}$ & $0 / 3$ & $0 / 8$ & - & - \\
\hline 7 & $35 / \mathrm{F}$ & $\begin{array}{l}\text { ECG } \\
\text { abnormality }\end{array}$ & 6 years & V1-V5 & + & ND & ND & $3 / 3$ & $10 / 11$ & + & + \\
\hline 8 & $30 / \mathrm{F}$ & Family history & Asymptomatic & V1-V3 & - & - & $\begin{array}{l}\text { Fat, } \\
\text { fibrosis }\end{array}$ & $1 / 3$ & $5 / 10$ & - & - \\
\hline 9 & $28 / \mathrm{M}$ & VT & 16 years & IRBBB & - & + & $\begin{array}{l}\text { Fat, } \\
\text { fibrosis }\end{array}$ & $1 / 3$ & $5 / 10$ & - & + \\
\hline 10 & $23 / M$ & Family history & Asymptomatic & V1 & - & + & Fibrosis & $0 / 3$ & $0 / 10$ & - & + \\
\hline 11 & $22 / \mathrm{F}$ & Family history & Asymptomatic & $\mathrm{V} 1-\mathrm{V} 3$ & - & - & $\begin{array}{l}\text { Fat, } \\
\text { fibrosis }\end{array}$ & $2 / 3$ & $1 / 10$ & - & - \\
\hline 12 & $27 / \mathrm{M}$ & Family history & Asymptomatic & $\mathrm{V} 1-\mathrm{V} 2$ & - & - & $\begin{array}{l}\text { Fat, } \\
\text { fibrosis }\end{array}$ & $0 / 3$ & $3 / 10$ & - & + \\
\hline 13 & $59 / \mathrm{M}$ & VT & 9 years & $\mathrm{V} 1-\mathrm{V} 4$ & - & + & $\begin{array}{l}\text { Fat, } \\
\text { fibrosis }\end{array}$ & $3 / 3$ & $9 / 9$ & + & + \\
\hline 14 & $48 / \mathrm{M}$ & VT & 10 years & V1-V6 & + & + & $\begin{array}{l}\text { Fat, } \\
\text { fibrosis }\end{array}$ & $3 / 3$ & $12 / 12$ & + & - \\
\hline 15 & $30 / \mathrm{M}$ & VT & $<1$ year & V1-V5 & - & - & $\begin{array}{l}\text { Fat, } \\
\text { fibrosis }\end{array}$ & $2 / 3$ & $7 / 9$ & - & + \\
\hline
\end{tabular}

A, number of abnormal dimensions or wall motion score in the individual patient; E, epsilon; E:A, early to late diastolic ratio; F, female; IRBBB, incomplete right bundle branch block; M, male; ND, not done; RV, right ventricular; SAECG, signal average ECG; SVT, supraventricular tachycardia; T, total number of measured dimensions or segments; TAM, tricuspid annular motion at lateral position; VT, ventricular tachycardia, WM, wall motion. 
ratio of peak early to late diastolic (E:A) flow velocities were calculated.

In the patient group, superior vena cava flow was measured from the right supraclavicular fossa by placing the sample volume at a depth of $5-7 \mathrm{~cm}$. Venous peak flow velocities were measured in systole and diastole and the systolic to diastolic ratio was calculated. Tricuspid regurgitation was estimated semiquantitatively by colour and spectral continuous wave Doppler and graded as mild, moderate, or severe. All studies were recorded on both videotape and strip chart recordings ( 50 or $100 \mathrm{~mm} / \mathrm{s}$ ) with simultaneous ECG, and with a respiration trace obtained from a nasal thermistor.

ANALYSIS OF ECHOCARDIOGRAPHIC DATA

To minimise bias the echocardiograms from patients and normal subjects were coded and mixed with eight other echocardiograms, three from patients investigated because of ventricular arrhythmia and five from patients with a family history of ARVC. None of these patients fulfilled the criteria for ARVC and their data are not reported in this paper. In order to estimate reproducibility, the echocardiograms of all but one patient and 14 normal subjects were interpreted by two independent experienced observers (LL and UW), each blinded to the other's findings and to the patients or subjects.
One observer (LL), blinded to the subjects' status, interpreted the remaining echocardiograms.

From the videotape, cross sectional measurements of the right ventricular cavity were made on end diastolic frames and from three consecutive cardiac cycles. From the standard parasternal long axis view the right ventricular outflow tract was measured from the right ventricular anterior wall to the right side of the interventricular septum (fig 2A). From the apical four chamber view the minor axis of the inflow tract was measured within one third of the distance below the tricuspid valve annulus towards the apex, and the right ventricular body was measured by taking the maximum dimension of the middle third of the right ventricle (fig $2 \mathrm{~F}$ ).

The absolute measurements were corrected for body surface area and were considered increased if they equalled or exceeded the mean value $+2 \mathrm{SD}$ of the normal subjects. Right ventricular wall motion was subjectively evaluated by dividing the ventricle into $12 \mathrm{seg}$ ments (R1-R12) (fig 2). The observers classified each segment as having normal wall motion, mild hypokinesia, severe hypokinesia, akinesia-dyskinesia (scored 0, 1, 2, and 3, respectively), or not visualised. To mimic the clinical situation, the data presented are from one observer only (LL). The interindividual variation was calculated for cavity dimensions and regional wall motion analysis. $\mathrm{M}$ mode and

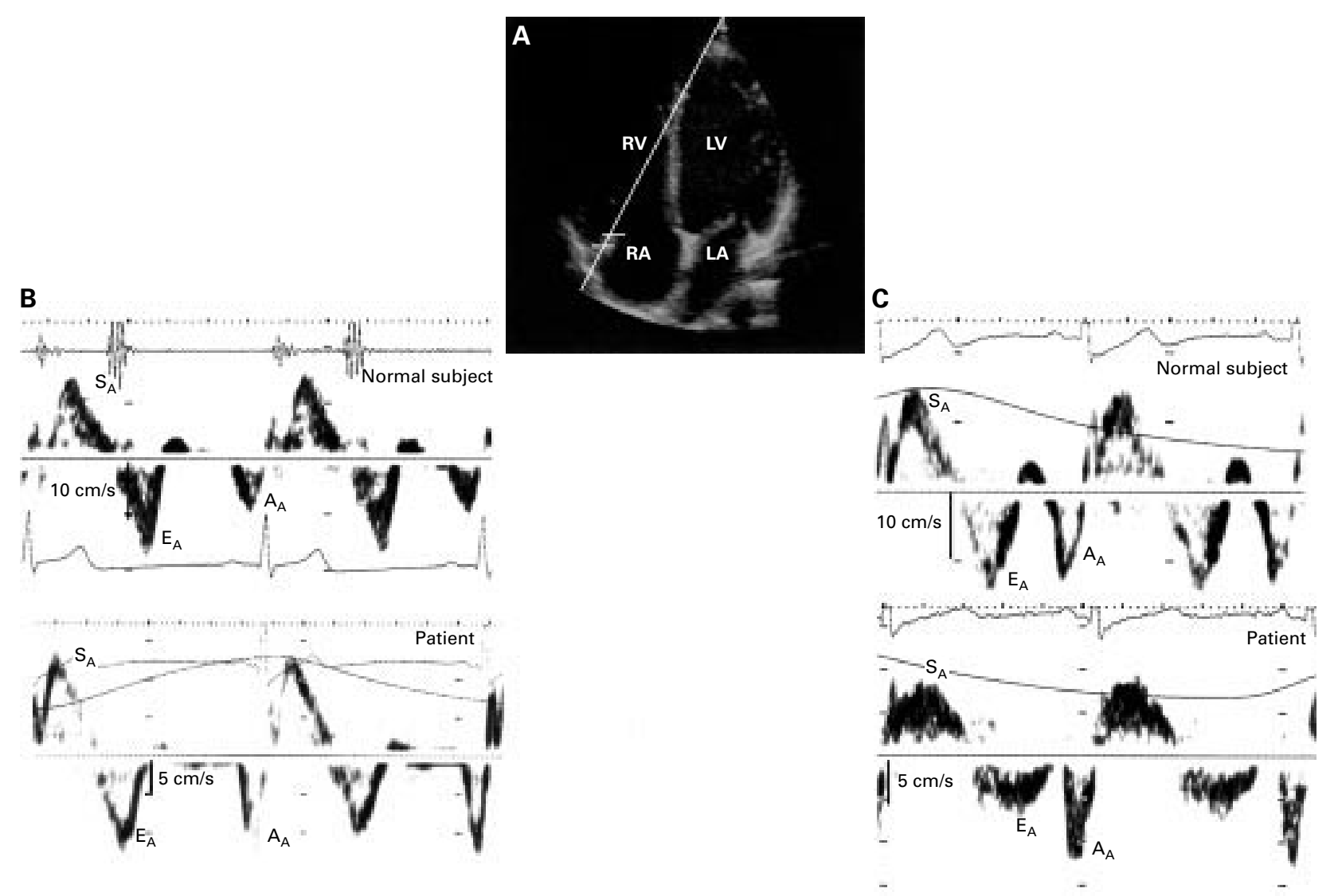

Figure 1 (A) Pulsed tissue Doppler recording of lateral tricuspid annulus motion. Guided by the cross sectional apical image, the sample volume was placed in the bright area of the tricuspid annulus, trying to align the cursor as parallel to the motion as possible. (B) Pulsed tissue Doppler recordings from a normal subject aged 26 years and a patient aged 27 years. (C) Pulsed tissue Doppler recordings from a normal subject aged 47 years and a patient aged 49 years. Note the decreased early diastolic annular velocity with increasing age in normal subjects and in patients with arrhythmogenic right ventricular cardiomyopathy compared with age matched normal controls. The systolic peak annular velocity is also slightly decreased in the patients. $A_{A}$, late diastolic peak annular velocity; $E_{A}$, early diastolic peak annular velocity; $L A$, left atrium; $L V$, left ventricle; $R A$, right atrium; $R V$, right ventricle; $S_{A}$, systolic peak annular velocity. 
Table 2 Right ventricular cavity dimensions in normal subjects and in patients with arrhythmogenic right ventricular cardiomyopathy (measurements corrected for body surface area $\left.\left(\mathrm{cm} / \mathrm{m}^{2}\right)\right)$

\begin{tabular}{|c|c|c|c|c|c|c|}
\hline & \multicolumn{2}{|l|}{$R V O T$} & \multicolumn{2}{|l|}{$R V I T$} & \multicolumn{2}{|l|}{$R V B$} \\
\hline & Mean (SD) & Range & Mean (SD) & Range & Mean (SD) & Range \\
\hline $\begin{array}{l}\text { Normal } \\
\text { subjects } \\
\text { (n) }\end{array}$ & $\begin{array}{l}1.6(0.2) \\
(19)\end{array}$ & 1.2 to 2.1 & $\begin{array}{l}1.8(0.2) \\
(22)\end{array}$ & 1.4 to 2.1 & $\begin{array}{l}1.2(0.1) \\
(21)\end{array}$ & 1.0 to 1.5 \\
\hline $\begin{array}{l}\text { ARVC } \\
\text { patients } \\
\text { (n) }\end{array}$ & $\begin{array}{l}2.0(0.6)^{\star} \\
(15)\end{array}$ & 1.3 to 3.4 & $\begin{array}{l}2.1(0.5)^{\star \star} \\
(15)\end{array}$ & 1.3 to 3.2 & $\begin{array}{l}1.6(0.6)^{\star \star} \\
(15)\end{array}$ & 1.1 to 3.1 \\
\hline
\end{tabular}

${ }^{\star} \mathrm{p}<0.05 ;{ }^{\star \star} \mathrm{p}<0.01$ for comparisons between patients and normal subjects. $\mathrm{n}$, number of measurements at different positions; RVB, right ventricular body; RVIT, right ventricular inflow tract; RVOT, right ventricular outflow tract.

Doppler variables were measured manually on the strip chart or the still frame of the video screen, the average of three to five beats being reported. Technically suboptimal recordings were excluded.

\section{STATISTICAL ANALYSIS}

Continuous data are presented as mean (SD). Group comparisons were made using the unpaired Student $t$ test, and a probability value of $p<0.05$ was considered significant. The interobserver variability for right ventricular dimensions was expressed as the mean difference $\left(\mathrm{mean}_{\text {diff }}\right)$ and $1 \mathrm{SD}$ of the difference $\left(\mathrm{SD}_{\text {diff }}\right)$. The coefficient of variance was calculated by the formula: ( $\mathrm{SD}_{\text {diff }} /$ mean value) $\times 100 \%$. Cohen's weighted $\kappa$ test $\left(\kappa_{\mathrm{w}}\right)$ was used to estimate the interobserver agreement of right ventricular wall motion analysis beyond chance occurrence. ${ }^{14}$ The interpretations of $\kappa_{\mathrm{w}}$ values used were: $<0.2$, poor agreement; $0.21-$ 0.40 , fair agreement; $0.41-0.60$, moderate agreement; 0.61-0.80, good agreement; and $0.81-1.00$, very good agreement.

\section{Results}

CLINICAL CHARACTERISTICS

Thirteen patients (87\%) had an abnormal resting ECG with $T$ wave inversion in the right precordial leads (table 1). Abnormal late potentials were present in eight patients, judged from the signal averaged ECG recording, and an additional patient showed ventricular postexcitation waves (epsilon waves) on the standard ECG. ${ }^{1}$ Thus abnormal late potentials were considered present in nine of the patients $(60 \%)$.

RIGHT VENTRICULAR DIMENSIONS AND FUNCTION In all patients, all three cavity dimensions were adequately measured. In the normal subjects some measurements were excluded because of a suboptimal cross sectional image. Comparing the patient group with the normal subjects, all right ventricular dimensions were significantly increased (table 2).

Analysing individual patients, 11 (73\%) showed dilatation of the right ventricular body,

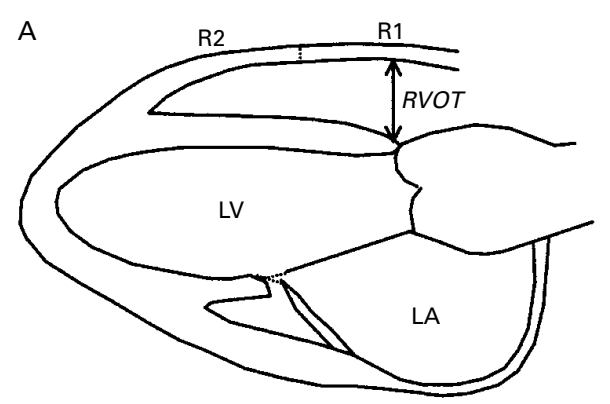

D

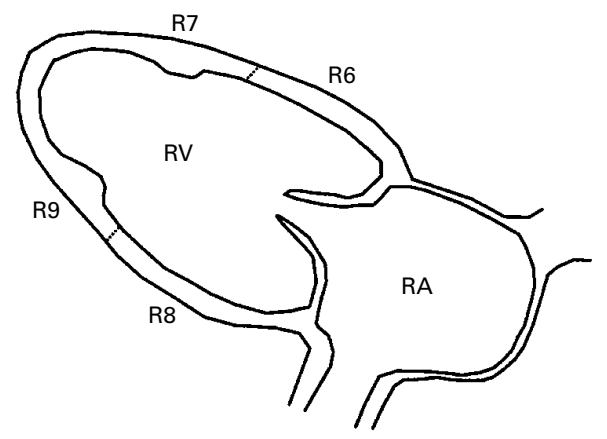

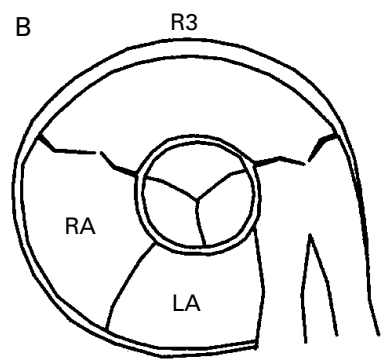

$E$

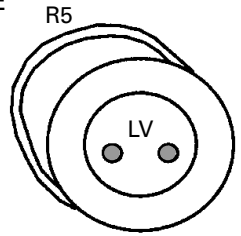

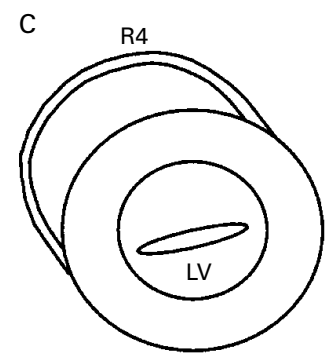

F

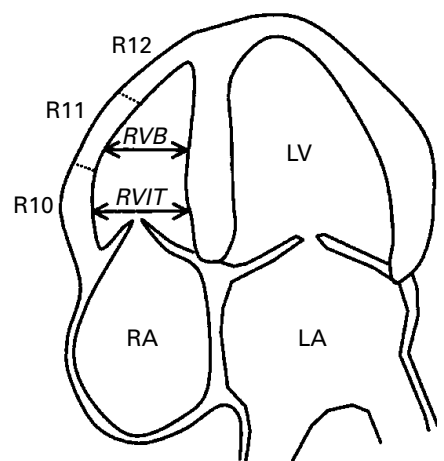

Figure 2 Definition of wall segments and cavity dimensions of the right ventricle. (A) Parasternal long axis view of the left heart: right ventricular outflow tract, measured from the anterior right ventricular free wall to the right side of the interventricular septum. (B) Parasternal short axis view at the aortic root level. (C) Parasternal short axis view at the mitral valve level. (D) Parasternal long axis view of the right ventricular inflow tract. (E)

Parasternal short axis view at the papillary muscle level. (F) Apical four chamber view: measurements of right ventricular inflow tract were taken within one third of the distance below the tricuspid annulus towards the right ventricular apex, and of the right ventricular body from the maximum short axis dimension in the middle third of the right ventricle. Segments R1, R2, and R3 correspond to the anterior wall of the outflow tract, R4, R6, and R7 to the anterior free wall, $R 5, R 8$, and $R 9$ to the inferior wall, and R10, R11, and R12 to the lateral free wall of the right ventricle. ${ }^{13} L A$, left atrium; LV, left ventricle; $R$, right ventricular segment; $R A$, right atrium; $R V$, right ventricle; $R V B$, right ventricular body; RVIT, right ventricular inflow tract; $R V O T$, right ventricular outflow tract. 
Table 3 Tricuspid annular motion assessed by $M$ mode echocardiography

\begin{tabular}{|c|c|c|c|c|}
\hline \multirow[b]{2}{*}{ Position } & \multicolumn{2}{|l|}{ Normal subjects } & \multicolumn{2}{|l|}{ ARVC patients } \\
\hline & $\begin{array}{l}\text { Total amplitude } \\
\text { (mm) }\end{array}$ & $\begin{array}{l}\text { Atrial amplitude } \\
(\mathrm{mm})\end{array}$ & $\begin{array}{l}\text { Total amplitude } \\
\text { (mm) }\end{array}$ & $\begin{array}{l}\text { Atrial amplitude } \\
(\mathrm{mm})\end{array}$ \\
\hline $\begin{array}{l}\text { Lateral } \\
\text { (n) }\end{array}$ & $\begin{array}{l}25.9(2.8) \\
(24)\end{array}$ & $\begin{array}{l}7.5(2.2) \\
(24)\end{array}$ & $\begin{array}{l}22.1(5.5)^{\star \star} \\
(15)\end{array}$ & $\begin{array}{l}8.0(1.8) \\
(15)\end{array}$ \\
\hline $\begin{array}{l}\text { Septal } \\
(\mathrm{n})\end{array}$ & $\begin{array}{l}15.9(2.1) \\
(15)\end{array}$ & $\begin{array}{l}4.4(0.9) \\
(15)\end{array}$ & $\begin{array}{l}13.6(2.2)^{\star} \\
(9)\end{array}$ & $\begin{array}{l}4.8(0.8) \\
(9)\end{array}$ \\
\hline $\begin{array}{l}\text { Posterior } \\
\text { (n) }\end{array}$ & $\begin{array}{l}21.5(2.7) \\
(21)\end{array}$ & $\begin{array}{l}5.9(1.5) \\
(21)\end{array}$ & $\begin{array}{l}18.2(5.5)^{\star} \\
(14)\end{array}$ & $\begin{array}{l}6.5(1.7) \\
(13)\end{array}$ \\
\hline $\begin{array}{l}\text { Anterior } \\
\text { (n) }\end{array}$ & $\begin{array}{l}22.0(2.1) \\
(23)\end{array}$ & $\begin{array}{l}7.0(1.9) \\
(23)\end{array}$ & $\begin{array}{l}21.3(4.8) \\
(15)\end{array}$ & $\begin{array}{l}8.3(2.1)^{\star} \\
(15)\end{array}$ \\
\hline
\end{tabular}

Data are mean (SD).

${ }^{\star} \mathrm{p}<0.05 ;{ }^{\star \star} \mathrm{p}<0.01$ for comparisons between patients and normal subjects.

ARVC, arrhythmogenic right ventricular cardiomyopathy; $n$, number of measurements at different positions.

eight $(53 \%)$ showed dilatation of the right ventricular outflow tract, and six $(40 \%)$ showed dilatation of the right ventricular inflow tract. In four patients $(27 \%)$ (cases 5, 6, 10, and 12), all dimensions were normal, and in five patients $(33 \%)$ (cases 3, 4, 7, 13, and 14) dilatation was present in all three positions (table 1).

Adequate $M$ mode recordings from the tricuspid annulus were obtained in all patients from the lateral and anterior positions. In some patients it was difficult to obtain adequate recordings from the septal and posterior positions. Comparing the patients with the normal subjects, the total amplitude was significantly decreased in all positions except the anterior (table 3). The anterior position on the other hand was the only site where the atrial amplitude was significantly different from the normal subjects, with increased amplitude. In six patients $(40 \%)$ (cases $2,3,4,7,13$, and 14 ), the total amplitude at the lateral position was decreased, defined as $\leqslant$ mean $-2 \mathrm{SD}$ of the value in the normal subjects (table 1).

Adequate pulsed tissue Doppler recordings were obtained in all patients in the lateral, posterior, and anterior positions and in 13 patients in the septal position. The tissue Doppler pattern of the patients differed significantly from the normal subjects (fig $1 \mathrm{~B}, \mathrm{C}$ ). The main finding was a significantly decreased annular velocity in early diastole $\left(\mathrm{E}_{\mathrm{A}}\right)$. In addition, a decreased peak systolic annular velocity $\left(S_{A}\right)$ was noted at the lateral point, and the peak late diastolic annular velocity $\left(A_{A}\right)$ was increased at the posterior point.

Calculating $\mathrm{E}_{\mathrm{A}}: \mathrm{A}_{\mathrm{A}}$ diastolic ratio, the patients showed significantly lower ratio at all four positions (table 4). Analysing the individual subjects, none of the normal subjects below the age of 36 years had an $\mathrm{E}_{\mathrm{A}}: \mathrm{A}_{\mathrm{A}}$ diastolic ratio at the lateral tricuspid annulus of less than 1.2. In contrast, five of seven patients $(71 \%)$ (cases $7,9,10,12$, and 15 ) below the age of 36 years had an $\mathrm{E}_{\mathrm{A}}: \mathrm{A}_{\mathrm{A}}$ diastolic ratio of $<1.0$ (table 1 ). One patient with advanced disease (case 14) had an $\mathrm{E}_{\mathrm{A}}: \mathrm{A}_{\mathrm{A}}$ diastolic ratio of 1.2 because of low peak annular velocity in late diastole. In the normal subjects, lower early diastolic peak annular velocities were observed in the older subjects compared with the young ones (fig $1 \mathrm{~B}$, C). All normal subjects older than 55 years had an $\mathrm{E}_{\mathrm{A}}: \mathrm{A}_{\mathrm{A}}$ diastolic velocity ratio of $<1.0$.

The tricuspid flow was adequately recorded in all patients and in 21 normal subjects.

Six patients had an increased peak velocity in late diastole (A) and a calculated early to late diastolic (E:A) ratio of $\leqslant 1.1$. Comparing the patient group with the normal subjects, the E:A ratio was significantly decreased, at $1.4(0.7) v$ $1.9(0.7)$, respectively $(p<0.05)$. Two patients (cases 4 and 14) had abnormal superior vena cava flow with a systolic to diastolic ratio of $<1$. Four patients showed mild tricuspid regurgitation and two patients had moderate regurgitation.

Regional wall motion was assessed subjectively in all patients. However, several segments were difficult to visualise adequately, especially those from the parasternal short axis view (R4-R5) and from the parasternal long axis view of the right ventricle (R7-R9) (table 5). Eleven patients $(73 \%)$ had abnormal wall motion in the lateral wall (R10-R12), nine $(60 \%)$ in the anterior wall of the outflow tract (R1-R3), eight $(53 \%)$ in the anterior wall (R4, $\mathrm{R} 6, \mathrm{R} 7)$, and six (40\%) in the inferior wall (R5, R8, R9) (table 5). Three patients (cases 5, 6, and 10) were judged to have normal regional wall motion and four patients (cases 3, 4, 13, and 14) to have abnormal wall motion in all segments. None of the normal subjects was classified as abnormal, the definition being that two observers independently scored the same segment as hypokinetic.

\section{INTEROBSERVER VARIABILITY}

The interobserver variability for measurements of right ventricular dimensions in the patients was as follows: mean $_{\text {diff }}\left(\mathrm{cm} / \mathrm{m}^{2}\right), 0.07,0.04$, and $0.11 ; \mathrm{SD}_{\text {diff }}, 0.26,0.17$, and 0.26 ; and coefficient of variance, $13 \%, 8 \%$, and $16 \%$, for right ventricular outflow tract, right ventricular inflow tract, and right ventricular body, respectively. The interobserver agreement for subjective assessment of regional wall motion was calculated for the visualised segments in the patients (110 segments) and in the normal subjects (72

Table 4 Tricuspid annular velocities $(\mathrm{cm} / \mathrm{s})$ assessed by pulsed tissue Doppler

\begin{tabular}{|c|c|c|c|c|c|c|c|c|c|c|}
\hline \multirow[b]{2}{*}{ Position } & \multicolumn{5}{|c|}{ Normal subjects } & \multicolumn{5}{|c|}{ ARVC patients } \\
\hline & $n$ & Systolic & $\begin{array}{l}\text { Early diastolic } \\
\left(E_{A}\right)\end{array}$ & $\begin{array}{l}\text { Late diastolic } \\
\left(A_{A}\right)\end{array}$ & $E_{A}: A_{A}$ ratio & $n$ & Systolic & $\begin{array}{l}\text { Early diastolic } \\
\left(E_{A}\right)\end{array}$ & $\begin{array}{l}\text { Late diastolic } \\
\left(A_{A}\right)\end{array}$ & $E_{A}: A_{A}$ ratio \\
\hline Lateral & 25 & $13.7(2.0)$ & $14.6(3.4)$ & 11.6 & $1.4(0.6)$ & 15 & $11.9(3.0)^{*}$ & $10.5(3.1)^{\star \star \star}$ & $11.6(3.0)$ & $0.9(0.3)^{\star \star}$ \\
\hline Septal & 17 & $8.8(1.3)$ & $13.6(3.7)$ & $7.6(1.8)$ & $1.9(0.7)$ & 13 & $8.4(2.2)$ & $9.8(3.9)^{\star}$ & $8.8(2.4)$ & $1.2(0.4)^{\star \star}$ \\
\hline Posterior & 22 & $11.3(2.0)$ & $14.9(4.4)$ & $9.2(3.0)$ & $1.9(0.9)$ & 15 & $10.1(2.4)$ & $9.8(3.9)^{\star \star}$ & $11.4(3.0)^{\star}$ & $0.9(0.4)^{\star \star \star}$ \\
\hline Anterior & 22 & $11.2(1.6)$ & $15.6(3.4)$ & $10.5(3.4)$ & $1.6(0.6)$ & 15 & $10.6(1.9)$ & $10.9(2.9)^{\star \star \star}$ & $12.6(3.9)$ & $1.0(0.5)^{\star \star \star \star}$ \\
\hline
\end{tabular}

Data are mean $(\mathrm{SD})$

${ }^{\star} \mathrm{p}<0.05 ;{ }^{\star \star} \mathrm{p}<0.01{ }^{\star \star \star} \mathrm{p}<0.001$ for comparisons between patients and normal subjects.

ARVC, arrhythmogenic right ventricular cardiomyopathy; $n$, number of measurements at different positions. 
Table 5 Results of regional right ventricular motion analysis with cross sectional echocardiography in 15 patients with arrythmogenic right ventricular cardiomyopathy

\begin{tabular}{lllllllllllll}
\hline Segment & $R 1$ & $R 2$ & $R 3$ & $R 4$ & $R 5$ & $R 6$ & $R 7$ & $R 8$ & $R 9$ & $R 10$ & $R 11$ & $R 12$ \\
\hline Normal motion & 8 & 6 & 8 & 4 & 1 & 7 & 4 & 6 & 3 & 5 & 5 & 4 \\
Mild hypokinesia & 2 & 4 & 3 & 2 & 1 & 5 & 4 & 4 & 3 & 5 & 5 & 6 \\
Severe hypokinesia & 4 & 4 & 1 & 1 & 1 & 2 & 3 & 0 & 1 & 5 & 2 & 2 \\
Akinesia or dyskinesia & 1 & 1 & 1 & 1 & 0 & 0 & 0 & 2 & 2 & 0 & 3 & 3 \\
Not visualised & 0 & 0 & 2 & 7 & 12 & 1 & 4 & 3 & 6 & 0 & 0 & 0 \\
Abnormal segments & $7 / 15$ & $9 / 15$ & $5 / 13$ & $4 / 8$ & $2 / 3$ & $7 / 14$ & $7 / 11$ & $6 / 12$ & $6 / 9$ & $10 / 15$ & $10 / 15$ & $11 / 15$ \\
\hline
\end{tabular}

The different segments are illustrated in fig 2 .

segments). The agreement in patients was moderate $\left(\kappa_{\mathrm{w}}=0.47\right)$ but poor in the normal subjects $\left(\kappa_{\mathrm{w}}<0.2\right)$. The interobserver variability for pulsed tissue Doppler recording has previously been estimated in our department. ${ }^{15}$ The coefficient of variance for the lateral tricuspid position was calculated to be $15 \%, 19 \%$, and $21 \%$ for the peak annular systolic, peak early, and peak late diastolic annular velocities, respectively (unpublished data).

\section{Discussion}

Previous echocardiographic studies on patients with ARVC have concentrated mainly on abnormalities of right ventricular dimensions and subjective wall motion analysis. ${ }^{16-18}$ Dilatation of the right ventricle, global dysfunction, wall thinning with localised aneurysm or outpouchings, and apical dyskinesia have all been considered typical findings. Various new echocardiographic modes have appeared, but their place in the echocardiographic assessment of patients with suspected ARVC has still not been tested. In this study, in addition to the classical cross sectional measurements we therefore performed $\mathrm{M}$ mode and pulsed tissue Doppler measurements of tricuspid annular motion and analysed the right ventricular and atrial inflow patterns. We will discuss the findings from the different examination modes individually and then analyse the value of obtaining these additional measurements.

CROSS SECTIONAL ECHOCARDIOGRAPHY

Measurements of right ventricular dimensions were obtained in all patients, and the interobserver variability was low. The right ventricular dimensions varied considerably, from no sign of right ventricular dilatation $(\mathrm{n}=4)$ to global dilatation $(n=5)$. This is in line with previous studies. ${ }^{16}{ }^{17}$ All segments could be assessed in all patients in the standard parasternal long axis and apical four chamber views. In contrast, it was quite often difficult to visualise certain segments adequately from the parasternal short axis and long axis views of the right ventricle. There was also considerable variation in wall motion abnormalities between patients, from normal regional wall motion in all segments $(n=3)$ to abnormal motion in all segments $(n=4)$. The obvious reason for this is variation in the duration of this progressive disease in the individual patients. In general, the longer the duration of the disease the more pathological the findings.

Wall motion analysis is subjective and difficult, especially in the right ventricle. However, interobserver agreement in the patient group was moderately good, while interobserver agreement in the normal subjects was poor. These findings indicate considerable difficulties in differentiating normal motion from mild hypokinesia, while consensus on the diagnosis of severe wall motion abnormalities was good.

\section{TRICUSPID ANNULAR MOTION}

Measurement of tricuspid annular motion from the apical view has been suggested as a method of estimating right ventricular systolic function. ${ }^{9}{ }^{10}$ However, there are few reports on the analysis of tricuspid annular motion in right ventricular disease. Descent of the right ventricular base is both sensitive and specific for the identification of patients with haemodynamically significant right ventricular infarction, ${ }^{19}$ and also the most powerful predictor of adverse outcome in patients with myocarditis. ${ }^{20}$

Different echocardiographic modes have been used in the assessment of tricuspid annular motion. Cross sectional echocardiography was described initially, ${ }^{10}$ followed by $M$ mode echocardiography, ${ }^{9}$ and finally by pulsed tissue Doppler. ${ }^{21} \mathrm{M}$ mode and pulsed tissue Doppler recordings contain the same information. Calculating the derivative of the $\mathrm{M}$ mode curve gives the instantaneous velocity, which can be measured directly using the tissue Doppler technique. This latter technique has so far mainly been used in left ventricular assessment. ${ }^{22}{ }^{23}$ In this study we applied both $M$ mode and pulsed tissue Doppler techniques. Information from the two techniques differed slightly. While $M$ mode showed a decreased total amplitude reflecting impaired systolic function, pulsed tissue Doppler was more sensitive in showing diastolic changes - that is, a decreased peak annular velocity in early diastole and a decreased $\mathrm{E}_{\mathrm{A}}: \mathrm{A}_{\mathrm{A}}$ ratio compared with normal subjects.

When analysing these recordings one must remember the age related changes with decreasing early diastolic peak annular velocities, increasing late diastolic peak annular velocities, and decreasing $\mathrm{E}_{\mathrm{A}}: \mathrm{A}_{\mathrm{A}}$ ratio with increasing age-findings in accordance with recently published results. ${ }^{24}$ In our study none of the normal subjects below the age of 36 years had an $\mathrm{E}_{\mathrm{A}}: \mathrm{A}_{\mathrm{A}}$ ratio lower than 1.2 at the lateral tricuspid annulus. In contrast, five of seven patients $(71 \%)$ below that age had an $\mathrm{E}_{\mathrm{A}}: \mathrm{A}_{\mathrm{A}}$ ratio of $\leqslant 1.0$. One of these patients had both normal right ventricular dimensions and visually normal regional motion. Two other patients showed normal or right ventricular dilatation at one site and only mild regional hypokinesia. An abnormal tissue Doppler pattern in diastole thus seems to give additional information over cross sectional 
measurements and may be an early objective sign of right ventricular myocardial dysfunction in patients with ARVC.

\section{RIGHT VENTRICULAR AND SYSTEMIC VENOUS} INFLOW

Doppler echocardiography of the right ventricular inflow and systemic venous inflow permits assessment of global right ventricular diastolic function. ${ }^{26}$ Six patients $(40 \%)$ in our study showed a tricuspid inflow pattern with increased late diastolic (A) peak velocity and decreased ratio of early (E) to late (A) diastolic peak flow velocities, a pattern indicating abnormal relaxation of the right ventricle. The patient group had a significantly decreased E:A ratio compared with the normal subjects, and this could not be explained by differences in heart rate. Abnormal tricuspid inflow has been reported in one previous study of ARVC patients but results were only reported from six patients. ${ }^{27}$ Two of our patients showed a severely abnormal superior vena caval inflow pattern, with a peak systolic to diastolic ratio of $<1$ indicating decreased ventricular compliance. ${ }^{28}$ Both patients had a tricuspid flow with an E:A ratio of $>1.5$ suggesting pseudonormalisation, and the tissue Doppler recording from the lateral tricuspid annulus showed a low late diastolic peak velocity suggesting atrial dysfunction or a greatly increased filling pressure. None of the patients had severe tricuspid regurgitation, which otherwise can influence the venous inflow pattern.

COMPARISON BETWEEN THE DIFFERENT MODES

Cross sectional echocardiographic assessment of right ventricular function was also possible with reasonable reproducibility when assessing segmental function. The findings varied from dysfunction in all segments to normal in all. This is not surprising because the clinical presentation varied from no symptoms to a symptom duration of 16 years. The poor interobserver agreement that we found when analysing data from normal subjects-in whom it was hard to differentiate normal motion from mild hypokinesia-should also be born in mind. The clinical conclusion from this is that subjective detection of early changes in wall motion may be difficult. Tricuspid annular motion with $\mathrm{M}$ mode or tissue Doppler was abnormal for the patient group as whole, and seems to be pathological at an earlier stage with pulsed tissue Doppler than when using the traditional cross sectional measures. Of great importance is the fact that this method is quantifiable and it should therefore be useful in both the diagnosis and the follow up of this patient group. When the analyses are combined with data on inflow variables, information can also be obtained about filling pressures.

\section{LIMITATIONS}

When recording the annular motion with pulsed tissue Doppler, it is not possible to keep the sample volume in the same position during the cardiac cycle. The velocity signal therefore includes velocities from adjacent ventricular and atrial walls.
Most of the patients were on $\beta$ blockers at the time of investigation. For ethical reasons, it was not possible to disrupt the drug regimen. To our knowledge, the effect of long term treatment with $\beta$ blockers on right ventricular diastolic variables and tissue Doppler pattern has not been investigated in humans. It is unlikely that this treatment was the cause of the changes found, as two of our patients below the age of 30 years were not on $\beta$ blockers and nevertheless showed an abnormal diastolic velocity pattern from the tricuspid annulus.

CONCLUSIONS

ARVC is a familiar right ventricular myocardial disease, usually manifested by ventricular arrhythmias and an accompanying risk of sudden death. It is important to establish the diagnosis at an early stage and to investigate relatives. Assessment of the right ventricle is difficult, requiring a combination of different echocardiographic modes. Our data suggest that subjective assessment of regional right ventricular function may be hard in patients with mild myocardial dysfunction and the results are likely to have poor reproducibility. Tricuspid annular measurements are valuable and easy to obtain with both $\mathrm{M}$ mode and tissue Doppler echocardiography. As they are quantifiable they are therefore useful in the follow up of patients. An abnormal diastolic velocity pattern with decreased early diastolic peak annular velocity and decreased early to late diastolic velocity ratio is probably an early but non-specific sign of the disease. Normal right ventricular dimensions do not exclude ARVC in young or middle aged patients.

This work was supported by the Swedish Medical Research Council (grant 9481), the Swedish Heart Lung Foundation (grant 41604), the Research Foundation of the University Hospital of Linköping (grant 98/080), and the Carldavid Jönsson Marie Gustavsson, Inger Ekman, and Chatarina Sved.

1 Marcus FI, Fontaine GH, Guiraudon G, et al. Right Marcus FI, Fontaine GH, Guiraudon $\mathrm{G}$, et al. Right
ventricular dysplasia: a report of 24 adult cases. Circulation ventricular dysplasia

2 Richardson P, McKenna W, Bristow M, et al. Report of the 1995 World Health Organisation/International Society and Federation of Cardiology task force on the definition and classification of cardiomyopathies. Circulation 1996;93: 841-2.

3 Pinamonti B, Di Lenarda A, Sinagra G, et al. Long-term evolution of right ventricular dysplasia-cardiomyopathy. Am Heart F 1995;129:412-15.

4 Thiene G, Nava A, Corrado D, et al. Right ventricular cardiomyopathy and sudden death in young people. $N$ Engl $\mathcal{F}$ Med 1988;318:129-33.

5 Furlanello F, Bertoldi A, Dallago M, et al. Cardiac arrest and sudden death in competitive athletes with arrhythmogenic right ventricular dysplasia. Pacing Clin Electrophysiol 1998;21:331-5.

physiol 1998;21:331-5.
6 Larsson E, Wesslén L, Lindquist O, et al. Sudden unLarsson E, Wesslen L, Lindquist $\mathrm{O}$, et al. Sudden unexpected cardiac deaths among young Swedish orienteers-morphological changes

organs. APMIS 1999;107:325-36.
7 McKenna WJ, Thiene G, Nava A, et al. Task force of the working group on myocardial and pericardial disease of the European Society of Cardiology and of the Scientific Council on Cardiomyopathies of the International Society and Federation of Cardiology. Diagnosis of arrhythmogenic right ventricular dysplasia/cardiomyopathy. $\mathrm{Br}$ Heart f 1994;71:215-18.

8 Feigenbaum H. Echocardiography, 5th ed. Philadelphia: Lea and Febiger, 1994:158-65.

9 Hammarström E, Wranne B, Pinto FJ, et al. Tricuspid annular motion. F Am Soc Echocardiogr 1991;4:131-9.

10 Kaul S, Tei C, Hopkins JM, et al. Assessment of right ventricular function using two-dimensional echocardioventricular function using two-diment Am Heart f 1984;107:526-31.

11 Breithardt G, Cain ME, El-Sherif N, et al. Standards for analysis of ventricular late potentials using high-resolution or signal-averaged electrocardiography: a statement by a 
task force committee of the European Society of Cardiol ogy, the American Heart Association, and the American College of Cardiology. Circulation 1991;83:1481-8.

12 Foale R, Nihoyannopoulos P, McKenna W, et al. Echocardiographic measurement of the normal adult righ ventricle. Br Heart f 1986;56:33-44

13 Weyman AE. Principles and practice of echocardiography, 2nd ed. Philadelphia: Lea and Febiger, 1994:901-21.

14 Altman DG. Practical statistics for medical research, 1st ed. London: Chapman and Hall. 1999:404-9.

15 Lindström L, Wranne B. Pulsed tissue Doppler evaluation of mitral annulus motion: a new window to assessment of diastolic function. Clin Physiol 1999;1:1-10

16 Manyari DE, Duff HJ, Kostuk WJ, et al. Usefulness of noninvasive studies for diagnosis of right ventricular dysplasia. Am 7 Cardiol 1986.57:1147-53.

17 Blomström-Lundqvist C, Beckman-Suurküla $M$, Wallentin $\mathrm{I}$, et al. Ventricular dimensions and wall motion assessed by echocardiography in patients with arrhythmogenic right echocardiography in patients with arrhythmogenic

18 Scognamiglio R, Fasoli G, Nava A, et al. Contribution of cross-sectional echocardiography to the diagnosis of right ventricular dysplasic

19 Goldberger JJ, Himelman RB, Wolfe CL, et al. Right ventricular infarction: recognition and assessment of its hemodynamic significance by two dimensional echocardiography. I Am Soc Echocardiogr 1991;4:140-6.

20 Mendes LA, Dec GW, Picard MH, et al. Right ventricular dysfunction: an independent predictor of adverse outcome in patients with myocarditis. Am Heart f 1994;128:301-7.
21 Isaaz K, Munoz del Romeral L, Lee E, et al. Quantitation of the motion of the cardiac base in normal subjects by Doppler echocardiography. I Am Soc Echocardiogr 1993;6:166-76.

22 Gulati VK, Katz WE, Follansbee WP, et al. Mitral annular descent velocity by tissue Doppler echocardiography as an index of global left ventricular function. Am 7 Cardiol 1996;77:979-84.

23 Wilkenshoff UM, Sovany A, Wigström L et al. Regional mean systolic myocardial velocity estimation by real-time color Doppler myocardial imaging: a new technique for cor qur 1998:11:683-92.

24 Alam M, Wardell J, Andersson E, et al. Characteristics of mitral and tricuspid annular velocities determined by pulsed wave Doppler tissue imaging in healthy subjects. $\mathcal{F}$ Am Soc Echocardiogr 1999;12:618-28.

25 Kukulski T, Hübbert L, Arnold M, et al. Normal regional right ventricular function and its change with age: a Doppler myocardial imaging study. I Am Soc Echocardiogr 2000;13:194-204.

26 Appleton CP, Jensen JL, Hatle LK, et al. Doppler evaluation of left and right ventricular diastolic function: a technical guide for obtaining optimal flow velocity recordings. $7 \mathrm{Am}$ guide for obtaining optimal flow velc

27 Iliceto S, Izzi M, De Martino G, et al. Echo Doppler evaluation of right ventricular dysplasia. Eur Heart $\mathcal{F} 1989$; 10(suppl D):29-32.

28 Sivaciyan V, Ranganathan N. Transcutaneous Doppler ugular venous flow velocity recording: clinical and hemodynamic correlates. Circulation 1978;57:930-9.

\section{Electronic pages}

\section{eHEART: www.heartjnl.com}

The following electronic only articles are published in conjunction with this issue of Heart (see also p 87).

\section{Rapid regression of primary pulmonary hypertension $C \mathcal{F}$ McMahon, $\mathcal{F}$ Kadkin, $M$ R Nihill}

A 14 month old child presented for investigation of tachypnoea. No parenchymal lung disease was shown on chest $x$ ray. On echocardiography there was normal intracardiac anatomy with significant pulmonary hypertension. At cardiac catheterisation the presence of primary pulmonary hypertension was confirmed, with a partial response to inhaled nitric oxide $(80 \mathrm{ppm})$ and $100 \%$ oxygen. The child was referred for assessment for heart-lung transplantation while maintained on oxygen, inhaled nitric oxide, and nifedipine. Repeat cardiac catheterisation two months after presentation showed complete normalisation of the pulmonary artery pressures.

(Heart 2001;86:e1) www.heartjnl.com/cgi/content/full/86/ $1 / \mathrm{e} 1$

\section{Leiomyosarcoma of the right ventricle extending into the pulmonary trunk $W$ Willaert, $P$ Claessens, $M$ Vanderheyden}

Primary leiomyosarcomas of the heart, particularly those affecting the right ventricle, are uncommon. A 70 year old woman presenting with the symptoms of progressive exertional dyspnoea and left sided pleuritic pain is presented. A leiomyosarcoma was diagnosed that originated in the right lateral ventricle wall, causing pulmonary outflow obstruction. Pathological analysis showed a neoplasm with a myxoid stroma, high mitotic activity, and nuclei expressing atypia. Immunohistochemical staining was found positive for vimentin and desmin. Seven months after complete surgical resection the tumour relapsed. This case illustrates the poor outcome, high relapse rate, and inefficiency of treatment associated with primary cardiac leiomyosarcomas. The current literature regarding incidence, diagnostic techniques, treatment strategies, and survival rates of this rare but terminal disease is reviewed.

(Heart 2001;86:e2) www.heartjnl.com/cgi/content/full/86/ $1 / \mathrm{e} 2$

\section{Catheter ablation of a monofocal premature ventricular complex triggering idiopathic ventricular fibrillation}

$S$ Takatsuki, H Mitamura, S Ogawa

A 62 year old man was admitted for evaluation of recurrent episodes of syncope. A surface ECG showed frequent repetitive premature ventricular complexes of right ventricular outflow tract origin. Ventricular fibrillation was inducible by programmed electrical stimulation but otherwise cardiac evaluation was unremarkable. A diagnosis of idiopathic ventricular fibrillation was made and an implantable cardioverter-defibrillator (ICD) was installed. However, spontaneous ventricular fibrillation recurred, requiring repeated ICD discharges. The ventricular fibrillation was reproducibly triggered by a single premature ventricular complex with a specific QRS morphology. Radiofrequency catheter ablation was carried out to eradicate this complex. No ventricular fibrillation has developed after this procedure, and the patient does not require drug treatment. (Heart 2001;86:e3) www.heartjnl.com/cgi/content/full/86/ $1 / \mathrm{e} 3$ 